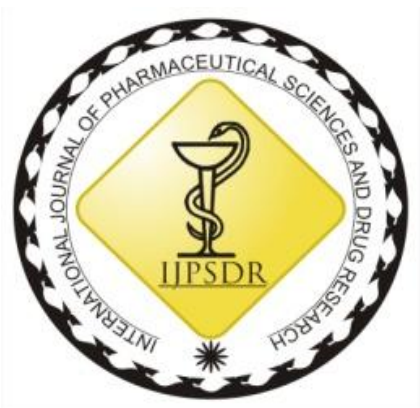

\author{
RESEARCH ARTICLE
}

ISSN: 0975-248X

CODEN (USA): IJPSPP

(co) EY-No-sA

\title{
Phytochemical Composition, in vitro Studies on $\alpha$-Amylase and $\alpha$-Glucosidase Inhibitory Activity of Selected Mangrove Plants
}

\author{
Ranjana*, B. L. Jadhav \\ Department of Life Sciences, University of Mumbai, Vidyanagari Campus, Santacruz (East)-400098, Mumbai, India
}

Copyright (C) 2019 Ranjana et al. This is an open access article distributed under the terms of the Creative Commons Attribution-NonCommercialShareAlike 4.0 International License which allows others to remix, tweak, and build upon the work non-commercially, as long as the author is credited and the new creations are licensed under the identical terms.

\begin{abstract}
The purpose of this study is to show the phytochemical composition and in vitro antidiabetic potential in the leaves of Ceriops tagal, Bruguiera cylindrica, and Salvadora persica mangrove plants. The phytochemical composition was studied by qualitative analysis. To determine in vitro antidiabetic activity leaves were subjected to solvent extraction by the Soxhlet method using methanol, ethanol, ethyl acetate, and pet ether and $\alpha$-amylase, $\alpha$-glucosidase inhibition assays were performed. The findings indicates that alkaloid, steroid, flavonoid, terpenoid, glycosides, tannin, saponin, phenol, quinones and coumarin principles are present in the leaves of selected mangrove species. Among the selected mangrove species $C$. tagal leaves recorded the highest antidiabetic activity for both the assay followed by B. cylidrica and S. persica. Overall C. tagal was found highly potent in the antidiabetic activity.
\end{abstract}

Keywords: Mangroves, In vitro, Antidiabetic activity, $\alpha$-glucosidase, $\alpha$-amylase.

*Corresponding author: Ms. Ranjana

Address: Department of Life Sciences, University of Mumbai, Vidyanagari Campus, Santacruz (East)-400098, Mumbai, India

E-mail $\bowtie$ : ranjanaram987@gmail.com

Relevant conflicts of interest/financial disclosures: The authors declare that the research was conducted in the absence of any commercial or financial relationships that could be construed as a potential conflict of interest.

Received: 11 July, 2019; Revised: 07 August, 2019; Accepted: 14 August, 2019; Published: 25 September, 2019

\section{INTRODUCTION}

Diabetes mellitus, characterized by both elevated production and low utilization of glucose, could be a major endocrine disorder touching nearly $10 \%$ of the population throughout the world. [1] It is a long lasting condition that solemnly affects a person's life, characterized by metabolic disorders in carbohydrate, fat, and protein and resulting in hyperglycemia. [2] Since centuries, plants are consistently been an admirable source of medicines and drugs available today, which are derived from plants to overcome a wide variety of clinical diseases. Mangroves are woody plants growing in marshy areas in tropical and subtropical regions where they do exist in relatively high salinity, utmost tides, robust winds, high temperatures and filthy, anaerobic soils. [3-4] To thrive in these extreme conditions, they synthesize diverse classes of secondary metabolites responsible for various medicinal properties. Mangrove plants are used traditionally in folk medicines to treat various diseases such as skin disorders, sores, leprosy, angina pectoris, asthma, tuberculosis, constipation, convulsions, diarrhoea, dysentery, elephantiasis, eye ailments, fever, headaches, haemorrhage, inflammation, malaria, jaundice, fungal infections, kidney stones, lesions, malignancies, rheumatism, sore throat, and syphilis. They are also used as an astringent, emmenagogue, hemostat, styptic, expectorant, and tonic. [5] A few 
species like Acanthus ilicifolius [6], C. tagal [7-8], Rhizophora mucronata [9-10], Diospyros peregrine ${ }^{[11]}$ and Heritiera fomes [12] are used as folklore medicine to cure diabetes. Besides folklore uses, many mangrove species like $R$. mucronata [13-14], Xylocarpus moluccensis [15], Sonneratia apetala [16], Drosera heterophylla and S. alba [17], C. decandra [18] scientifically proved active against the hyperglycaemic activity. Mangrove plants are the major source of phytoconstituents like phenolic compounds, flavonoids, terpenoids, saponin, coumarins, glycopeptide, alkaloids, tannin, essential oils, anthraglycosides [19-22] and other constituents rich in plant products tend to show a reduction in blood glucose levels. [23] They can also maintain the function of $\beta$-cells by hampering the formation of diabetesinduced reactive oxygen species. [24] Mangrove possesses secondary metabolites in abundance such as alkaloid, saponin, flavonoid, tannin and they are proved to have antidiabetic activity. [25-28] We have selected C. tagal, B. cylindrica and S. persica mangrove species, thereafter studied their phytochemical compositions and in vitro antidiabetic potential in this study.

\section{MATERIALS AND METHODS \\ Plant Material}

Three mangrove plants C. tagal, B.cylindrica, and S.persica leaves were collected in May from the Gorai beach area located at $19^{\circ} 15^{\prime} 0^{\prime \prime} \mathrm{N}$ and $72^{\circ} 46^{\prime} 59^{\prime \prime} \mathrm{E}$ Borivali, Mumbai, Maharashtra, India and recognised by a taxonomist. The leaves were washed under running water to get them free from dust and other contaminants followed by oven-drying at $40^{\circ} \mathrm{C}$ to remove any moisture, ground, and the powder was sieved through a muslin cloth for further uses of the extract preparation.

\section{Extract Preparation}

Different solvent leaves extracts were prepared from the selected plants' leaves. $10 \mathrm{~g}$ leaf powder of all the three mangroves was added with the $200 \mathrm{~mL}$ methanol, ethanol, ethyl acetate and pet ether (polar to non-polar) using the Soxhlet apparatus. The extracts obtained were concentrated using a rotary flash evaporator (Buchi, Japan) to get the residues and used for antidiabetic activity.

\section{Phytochemical Analysis}

The qualitative estimation of secondary metabolites in methanol leaf extract was studied as per Harborne. [29] The tests for various classes of secondary metabolites were as follows.

Alkaloids: $0.2 \mathrm{ml}$ extract was taken and $0.2 \mathrm{ml} \mathrm{HCl}$ was added. 2-3 drops of Dragendorff's reagent was added to the mixture and then the orange or red precipitate and turbid solution indicate the presence of alkaloids.

Tannins: $2 \mathrm{ml}$ of water was added to $0.2 \mathrm{ml}$ extract followed by heating on a water bath for $10 \mathrm{~min}$. The mixture was filtered; $\mathrm{FeCl}_{3}$ was added to the filtrate and observed for the dark green solution which indicates the presence of tannin.
Terpenoids: In a test tube, $0.2 \mathrm{ml}$ extract was mixed with $0.2 \mathrm{ml}$ chloroform. Conc. $\mathrm{H}_{2} \mathrm{SO}_{4}$ was added to this cautiously to form a layer. The presence of reddishbrown colour at the interface indicated that terpenoids are present.

Glycosides: $0.2 \mathrm{ml}$ extract was mixed with $0.2 \mathrm{ml}$ acetic acid and $0.2 \mathrm{ml}$ of chloroform and then it was chilled on ice. $\mathrm{H}_{2} \mathrm{SO}_{4}$ was added carefully and the colour change from violet to blue and then to green confirmed the existence of the steroidal nucleus (Aglycone portion of glycoside).

Steroids: $0.2 \mathrm{ml}$ extract was added to $0.2 \mathrm{ml}$ chloroform followed by $0.2 \mathrm{ml}$ Conc. $\mathrm{H}_{2} \mathrm{SO}_{4}$. The red colour in the lower layer of chloroform indicated the presence of steroids.

Saponins: A mixture of $0.2 \mathrm{ml}$ extract and $5 \mathrm{ml}$ distilled water was shaken vigorously and was observed for a stable persistent froth. After adding 3 drops of olive oil, the formation of stable foam confirmed the presence of saponins.

Flavonoids: $0.2 \mathrm{ml}$ plant extract was mixed with dilute $\mathrm{NaOH}$ solution followed by dilute $\mathrm{HCl}$. The change of yellow solution into a colourless one indicates the presence of flavonoids.

Phlobatannins: The red precipitate after mixing $2 \mathrm{ml}$ extract in $1 \%$ aqueous $\mathrm{HCl}$, witnessed the presence of phlobatannin.

Anthocyanins: $2 \mathrm{ml}$ extract was added in $2 \mathrm{ml} 2 \mathrm{~N} \mathrm{HCl}$ containing ammonia. Pink-red color turns into blueviolet which shows the presence of anthocyanins.

Coumarins: The yellow colour solution after adding 2 $\mathrm{ml}$ extract in $10 \% \mathrm{NaOH}$ confirms the presence of coumarins.

Phenolics: Addition of $1 \mathrm{ml}$ extract in $0.5 \mathrm{ml} \mathrm{1 \%}$ Lead acetate and $1 \% \mathrm{FeCl}_{3}$ gave a blue-black and greenbrown precipitate respectively.

Quinones: $3 \mathrm{ml}$ Conc. $\mathrm{HCl}$ was added in the $2 \mathrm{ml}$ extract. The green color was obtained, indicating quinones are present in the extracts.

\section{In vitro Antidiabetic Activity}

The antidiabetic activity was estimated by a-amylase [30] and a-glucosidase inhibition assays [31] as described below:

\section{a-amylase Inhibition Assay}

A mixture of $100 \mu \mathrm{L}$ plant extract and $100 \mu \mathrm{L} 0.02 \mathrm{M}$ sodium phosphate buffer ( $\mathrm{pH}$ 6.9) containing $a$-amylase solution was kept for incubation at $37^{\circ} \mathrm{C}$ for $30 \mathrm{~min}$. In each tube, $800 \mu \mathrm{L} 1 \%$ starch solution in $0.02 \mathrm{M}$ sodium phosphate buffer ( $\mathrm{pH}$ 6.9) was added and kept again for incubation at $37^{\circ} \mathrm{C}$ for 15 min followed by addition of $1 \mathrm{ml}$ dinitrosalicylic acid (DNSA) reagent. All the test tubes were then placed in a boiling water bath for $5 \mathrm{~min}$ and the optical density was measured at $540 \mathrm{~nm}$.

a-glucosidase Inhibition Assay

A mixture containing plant extract, $1 \mathrm{ml}$ starch substrate $(2 \% \mathrm{w} / \mathrm{v}$ maltose) and $0.2 \mathrm{M}$ Tris buffer $(\mathrm{pH}$ 8.0) was kept for incubation at $37^{\circ} \mathrm{C}$ for $5 \mathrm{~min}$. The addition of $1 \mathrm{ml}$ of a-glucosidase enzyme $(1 \mathrm{U} / \mathrm{ml})$ followed by incubation at $35^{\circ} \mathrm{C}$ for $40 \mathrm{~min}$ initiates the 
reaction and further addition of $2 \mathrm{ml} 6 \mathrm{~N} \mathrm{HCl}$ terminates the reaction. Thereafter absorbance of the resultant colour was measured at $540 \mathrm{~nm}$.

Inhibitory Concentration $\left(\mathrm{IC}_{50}\right)$

Half-maximal Inhibitory concentration $\left(\mathrm{IC}_{50}\right)$ is the amount of a substance required to inhibit a biological process such as an enzyme, cell, cell receptor or microorganism by half. The $\mathrm{IC}_{50}$ value was calculated by non-linear regression analysis of $\%$ inhibition recorded for different concentrations of test substances/standard. The relative activity of the sample was determined by comparing the $\mathrm{IC}_{50}$ value of a sample with the standard. Higher the $\mathrm{IC}_{50}$ value, lower will be the relative activity in comparison to standard and vice-versa. Acarbose was used as the standard and all tests were carried out in triplicate. Percentage inhibition (I \%) was calculated by:

$$
\begin{aligned}
\% \text { Inhibition }= & \left(\text { Absorbance }_{\text {control }}-\text { Absorbance }_{\text {sample }}\right) / \\
& \left(\text { Absorbance }_{\text {control }}\right) \times 100
\end{aligned}
$$

Where Absorbance $_{\text {control }}=$ absorbance of the solution with no extract

Absorbance sample $=$ absorbance of the solution containing extract and enzyme solution

\section{Statistical analysis}

All the data are means of three independently performed experiments and shown as means \pm SD. Their significance was tested by one-way ANOVA (SPSS ver-21; IBM Japan Ltd., Tokyo, Japan) followed by Post hoc Duncan's test at significance level $P<0.05$.

\section{RESULTS}

The result of phytochemical analysis has shown the presence of alkaloid, steroid, flavonoid, terpenoid, glycosides, tannin, saponin, phenol, quinones and coumarin in all the selected mangrove species (Table 1). The a-amylase inhibition assay of $C$. tagal leaves has shown a gradual increase in percent inhibition as concentration increases for all the extracts. In this plant best percent inhibition was recorded in methanol extract $(73.26 \%)$ followed by ethanol $(62.76 \%)$, ethyl acetate $(61.83 \%)$ and pet ether $(54.55 \%)$ extracts at highest concentration $(5 \mathrm{mg} / \mathrm{ml})$ (Table 2). The percent inhibition and $\mathrm{IC}_{50}$ value for standard drug acarbose was $89.39 \%$ and $0.095 \mathrm{mg} / \mathrm{ml}$ respectively. Similarly, aglucosidase assay has shown the best percent inhibition $(66.13 \%)$ and $\mathrm{IC}_{50}$ value $(2.448 \mathrm{mg} / \mathrm{ml})$ for methanol extract (Table 5).
A similar dose-dependent pattern of inhibition was seen in B. cylindrica leaves for all the extracts. The methanol extract registered significant percent inhibition $(69.23 \%)$ and $\mathrm{IC}_{50}(3.027 \mathrm{mg} / \mathrm{ml})$ for aamylase inhibition assay (Table 3 ) The lower percent inhibition $(55.19 \%)$ and higher $\mathrm{IC}_{50}$ value $(4.266 \mathrm{mg} / \mathrm{ml})$ were recorded in pet ether extract of this plant. The results of a similar trend were observed in this plant with a-glucosidase inhibition assay (Table 6). The slightly lower antihyperglycaemic activity was recorded in S. persica leaves as compared to C. tagal and B. cylindrica. In this plant best percent inhibition $(59.82 \%)$ and $\mathrm{IC}_{50}$ value $(3.637 \mathrm{mg} / \mathrm{ml})$ was seen in methanol extract followed by ethanol, ethyl acetate, and pet ether extracts (Table 4). Similarly, the aglucosidase assay has shown the best percent inhibition and $\mathrm{IC}_{50}$ value $(62.41 \%, 3.797 \mathrm{mg} / \mathrm{ml})$ for methanol extract (Table 7).

Table 1: Phytochemical composition of selected mangrove species.

\begin{tabular}{cccc}
\hline $\begin{array}{c}\text { Phytochemical } \\
\text { constituents }\end{array}$ & C. tagal & B. cylindrica & S. persica \\
\hline Alkaloids & + & + & - \\
Tannins & + & + & + \\
Terpenoids & + & + & + \\
Glycosides & + & - & + \\
Steroids & + & - & + \\
Saponins & + & + & + \\
Flavonoids & + & + & + \\
Phlobatannins & + & - & + \\
Anthocyanins & + & + & + \\
Coumarins & + & + & + \\
Phenolics & + & + & + \\
Quinones & + & + & + \\
\hline
\end{tabular}

\section{DISCUSSION}

In the present study selected mangrove species C. tagal, $B$. cylindrica and $S$. persica have shown the presence of alkaloid, steroid, flavonoid, terpenoid, glycosides, tannin, saponin, phenol, quinones and coumarin. This indicates selected mangroves contain diverse classes of phytochemicals. Similar classes of secondary metabolites were seen in L. racemosa [19], S. alba [20], C. tagal [32], S. apetala [22] mangrove species. These results are in agreement with the present finding, therefore it is suggested that mangroves are affluent in a diverse range of phytoconstituents. In the present study, we have made leaves extracts of methanol, ethanol, ethyl acetate and pet ether of selected mangrove species and determined its antidiabetic activity using in vitro antidiabetic assays i.e. a-amylase and a-glucosidase inhibition assays.

Table 2: The percent inhibition of a- amylase by methanol, ethanol, ethyl acetate and pet ether extracts of $C$. tagal leaves at varying

\begin{tabular}{|c|c|c|c|c|c|c|c|c|c|c|}
\hline \multirow{2}{*}{$\begin{array}{c}\text { Conc. } \\
(\mathrm{mg} / \mathrm{ml})\end{array}$} & \multicolumn{2}{|c|}{ Acarbose } & \multicolumn{2}{|c|}{ Methanol } & \multicolumn{2}{|l|}{ Ethanol } & \multicolumn{2}{|c|}{ Ethyl acetate } & \multicolumn{2}{|c|}{ Pet ether } \\
\hline & \%inhibition & $\mathrm{IC}_{50}$ & \%inhibition & $\mathrm{IC}_{50}$ & \%inhibition & $\mathrm{IC}_{50}$ & \%inhibition & $\mathrm{IC}_{50}$ & \%inhibition & $\mathrm{IC}_{50}$ \\
\hline 0.5 & $50.32^{\mathrm{a}} \pm 0.292$ & & $21.06^{\mathrm{a}} \pm 0.106$ & & $17.52^{\mathrm{a}} \pm 0.476$ & & $15.63^{\mathrm{a}} \pm 0.186$ & & $8.383^{a} \pm 0.673$ & \\
\hline 1.0 & $57.1^{\mathrm{b}} \pm 0.165$ & & $38.97^{b} \pm 0.529$ & & $32.58^{\mathrm{b}} \pm 0.181$ & & $27.53^{b} \pm 0.252$ & & $14.22^{b} \pm 0.277$ & \\
\hline 2.0 & $70.25^{c} \pm 0.16$ & $0.095 \pm$ & $46.84^{c} \pm 0.274$ & $2.576 \pm$ & $39.04^{c} \pm 0.474$ & 3.129 & $36.42^{c} \pm 0.040$ & $3.435 \pm$ & $29.48^{c} \pm 0.296$ & $4.284 \pm$ \\
\hline 3.0 & $80.22^{\mathrm{d}} \pm 0.113$ & 0.007 & $55.33^{d} \pm 0.528$ & 0.029 & $53.54^{d} \pm 0.159$ & \pm 0.009 & $45.76^{\mathrm{d}} \pm 0.345$ & 0.002 & $35.58^{\mathrm{d}} \pm 0.212$ & \\
\hline 4.0 & $88.09 \mathrm{e} \pm 0.037$ & & $65.03^{e} \pm 0.049$ & & $62.05^{e} \pm 0.337$ & & $60.24 \mathrm{e} \pm 0.061$ & & $50.24 \mathrm{e} \pm 0.465$ & \\
\hline 5.0 & $89.39 \mathrm{f} \pm 0.87$ & & $73.26^{\mathrm{f}} \pm 0.571$ & & $62.76^{\mathrm{f}} \pm 0.219$ & & $61.83^{f} \pm 0.223$ & & $54.45^{\mathrm{f}} \pm 0.106$ & \\
\hline
\end{tabular}
concentrations. 
Table 3: The percent inhibition of a-amylase by methanol, ethanol, ethyl acetate and pet ether extracts of B. cylindrica leaves at varying concentrations.

\begin{tabular}{|c|c|c|c|c|c|c|c|c|c|c|}
\hline \multirow{2}{*}{$\begin{array}{l}\text { Conc. } \\
\text { (mg/ml) }\end{array}$} & \multicolumn{2}{|c|}{ Acarbose } & \multicolumn{2}{|c|}{ Methanol } & \multicolumn{2}{|c|}{ Ethanol } & \multicolumn{2}{|c|}{ Ethyl acetate } & \multicolumn{2}{|c|}{ Pet ether } \\
\hline & \%inhibition & $\mathrm{IC}_{50}$ & \%inhibition & $\mathrm{IC}_{50}$ & \%inhibition & $\mathrm{IC}_{50}$ & \%inhibition & $\mathrm{IC}_{50}$ & \%inhibition & $\mathrm{IC}_{50}$ \\
\hline 0.5 & $50.32^{a} \pm 0.292$ & & $19.34^{\mathrm{a}} \pm 0.329$ & & $15.86^{\mathrm{a}} \pm 0.048$ & & $12.53^{\mathrm{a}} \pm 0.261$ & & $3.33^{a} \pm 0.177$ & \\
\hline 1.0 & $57.1^{b} \pm 0.165$ & & $29.53^{b} \pm 0.345$ & & $23.66^{b} \pm 0.458$ & & $18.08^{b} \pm 0.191$ & & $12.77^{b} \pm 0.308$ & \\
\hline 2.0 & $70.25^{c} \pm 0.16$ & $0.095 \pm$ & $33.63^{c} \pm 0.172$ & $3.027 \pm$ & $31.28^{c} \pm 0.243$ & $3.455 \pm$ & $30.19 c \pm 0.579$ & $3.681 \pm$ & $28.17^{c} \pm 0.107$ & 4.266 \\
\hline 3.0 & $80.22^{\mathrm{d}} \pm 0.113$ & 0.007 & $53.90^{\mathrm{d}} \pm 0.457$ & 0.028 & $50.92^{\mathrm{d}} \pm 0.442$ & 0.013 & $46.59^{\mathrm{d}} \pm 1.195$ & 0.022 & $35.42^{\mathrm{d}} \pm 0.089$ & \pm 0.13 \\
\hline 4.0 & $88.09 \mathrm{e} \pm 0.037$ & & $63.98^{e} \pm 0.899$ & & $59.00 \mathrm{e} \pm 0.458$ & & $58.04 \mathrm{e} \pm 0.274$ & & $49.34 \mathrm{e} \pm 0.237$ & \\
\hline 5.0 & $89.39 \mathrm{f} \pm 0.87$ & & $69.23^{\mathrm{f}} \pm 0.618$ & & $62.12^{\mathrm{f}} \pm 0.554$ & & $60.15^{\mathrm{f}} \pm 0.587$ & & $55.19^{\mathrm{f}} \pm 0.149$ & \\
\hline
\end{tabular}

Table 4: The percent inhibition of a-amylase by methanol, ethanol, ethyl acetate and pet ether extracts of $S$. persica leaves at varying concentrations.

\begin{tabular}{|c|c|c|c|c|c|c|c|c|c|c|}
\hline \multirow{2}{*}{$\begin{array}{l}\text { Conc. } \\
(\mathrm{mg} / \mathrm{ml})\end{array}$} & \multicolumn{2}{|c|}{ Acarbose } & \multicolumn{2}{|c|}{ Methanol } & \multicolumn{2}{|c|}{ Ethanol } & \multicolumn{2}{|c|}{ Ethyl acetate } & \multicolumn{2}{|c|}{ Pet ether } \\
\hline & \%inhibition & $\mathrm{IC}_{50}$ & \%inhibition & $I_{50}$ & \%inhibition & $I C_{50}$ & \%inhibition & $\mathrm{IC}_{50}$ & \%inhibition & $I C_{50}$ \\
\hline 0.5 & $50.32^{a} \pm 0.292$ & & $18.84^{a} \pm 0.553$ & & $11.24^{a} \pm 0.144$ & & $10.39 a \pm 0.432$ & & $8.26^{a} \pm 0.025$ & \\
\hline 1.0 & $57.1^{\mathrm{b}} \pm 0.165$ & & $22.51^{b} \pm 0.306$ & & $18.11^{b} \pm 0.031$ & & $16.43^{b} \pm 0.837$ & & $10.70^{b} \pm 0.488$ & \\
\hline 2.0 & $70.25^{c} \pm 0.16$ & $0.095 \pm$ & $33.23^{b} \pm 0.553$ & $3.637 \pm$ & $27.81^{c} \pm 0.735$ & $4.047 \pm$ & $25.21^{\mathrm{c}} \pm 0.544$ & $4.609 \pm$ & $22.67^{c} \pm 0.046$ & $5.138 \pm$ \\
\hline 3.0 & $80.22^{\mathrm{d}} \pm 0.113$ & 0.007 & $45.71^{\mathrm{c}} \pm 0.737$ & 0.046 & $34.82^{d} \pm 0.392$ & 0.044 & $29.87^{d} \pm 0.062$ & 0.024 & $26.88^{d} \pm 0.141$ & 0.048 \\
\hline 4.0 & $88.09 \mathrm{e} \pm 0.037$ & & $57.32^{d} \pm 0.484$ & & $54.99 \mathrm{e} \pm 0.733$ & & $49.58^{e} \pm 0.125$ & & $43.28^{\mathrm{e}} \pm 0.538$ & \\
\hline 5.0 & $89.39^{f} \pm 0.87$ & & $59.82^{\mathrm{e}} \pm 0.307$ & & $58.08^{f} \pm 0.309$ & & $51.95^{\mathrm{f}} \pm 0.330$ & & $47.42^{\mathrm{f}} \pm 0.375$ & \\
\hline
\end{tabular}

Table 5: The percent inhibition of a-glucosidase by methanol, ethanol, ethyl acetate and pet ether extracts of $C$. tagal leaves at varying concentrations.

\begin{tabular}{|c|c|c|c|c|c|c|c|c|c|c|}
\hline \multirow{2}{*}{$\begin{array}{l}\text { Conc. } \\
(\mathrm{mg} / \mathrm{ml})\end{array}$} & \multicolumn{2}{|c|}{ Acarbose } & \multicolumn{2}{|c|}{ Methanol } & \multicolumn{2}{|c|}{ Ethanol } & \multicolumn{2}{|c|}{ Ethyl acetate } & \multicolumn{2}{|c|}{ Pet ether } \\
\hline & \%inhibition & $I_{50}$ & \%inhibition & $I_{50}$ & \%inhibition & $I_{50}$ & \%inhibition & $\mathrm{IC}_{50}$ & \%inhibition & $I_{50}$ \\
\hline 0.5 & $50.61^{a} \pm 0.429$ & & $31.38^{a} \pm 0.421$ & & $16.27^{a} \pm 0.314$ & & $13.65^{a} \pm 0.182$ & & $6.37 \mathrm{a} \pm 0.475$ & \\
\hline 1.0 & $56.86^{\mathrm{b}} \pm 0.494$ & & $40.31^{\mathrm{b}} \pm 0.420$ & & $29.35^{b} \pm 0.103$ & & $26.06^{\mathrm{b}} \pm 0.282$ & & $14.55^{b} \pm 0.579$ & \\
\hline 2.0 & $70.23^{c} \pm 0.399$ & $0.059 \pm$ & $49.14^{c} \pm 0.359$ & $2.448 \pm$ & $40.18 \_ \pm 0.157$ & $3.633 \pm$ & $36.61^{c} \pm 0.464$ & $3.519 \pm$ & $30.40^{c} \pm 0.455$ & $4.235 \pm$ \\
\hline 3.0 & $82.00^{\mathrm{d}} \pm 1.525$ & 0.035 & $56.33^{d} \pm 0.295$ & 0.001 & $46.78^{\mathrm{d}} \pm 0.441$ & 0.018 & $43.49^{\mathrm{d}} \pm 0.486$ & 0.019 & $36.47^{d} \pm 0.331$ & 0.029 \\
\hline 4.0 & $86.67 \mathrm{e} \pm 01.587$ & & $62.86^{e} \pm 0.461$ & & $60.87 \mathrm{e} \pm 0.353$ & & $57.27 \mathrm{e} \pm 0.324$ & & $50.21^{e} \pm 0.454$ & \\
\hline 5.0 & $89.26^{\mathrm{f}} \pm 0.156$ & & $66.13^{\mathrm{f}} \pm 0.419$ & & $61.80^{\mathrm{f}} \pm 0.352$ & & $61.76^{\mathrm{f}} \pm 0.443$ & & $54.80^{\mathrm{f}} \pm 0.498$ & \\
\hline
\end{tabular}

Table 6: The percent inhibition of a-glucosidase by methanol, ethanol, ethyl acetate and pet ether extracts of B. cylindrica leaves at varying concentrations.

\begin{tabular}{|c|c|c|c|c|c|c|c|c|c|c|}
\hline \multirow{2}{*}{$\begin{array}{l}\text { Conc. } \\
\text { (mg/ml) }\end{array}$} & \multicolumn{2}{|c|}{ Acarbose } & \multicolumn{2}{|c|}{ Methanol } & \multicolumn{2}{|c|}{ Ethanol } & \multicolumn{2}{|c|}{ Ethyl acetate } & \multicolumn{2}{|c|}{ Pet ether } \\
\hline & \%inhibition & $I C_{50}$ & \%inhibition & $\mathrm{IC}_{50}$ & \%inhibition & $\mathrm{IC}_{50}$ & \%inhibition & $\mathrm{IC}_{50}$ & \%inhibition & $\mathrm{IC}_{50}$ \\
\hline 0.5 & $50.61^{\mathrm{a}} \pm 0.429$ & & $23.75^{a} \pm 0.257$ & & $14.61^{a} \pm 0.815$ & & $12.54^{a} \pm 0.376$ & & $8.06^{a} \pm 0.252$ & \\
\hline 1.0 & $56.86^{b} \pm 0.494$ & & $26.21^{b} \pm 0.510$ & & $23.79^{b} \pm 0.384$ & & $19.96^{b} \pm 0.124$ & & $10.55^{b} \pm 0.411$ & \\
\hline 2.0 & $70.23^{c} \pm 0.399$ & $0.059 \pm$ & $33.09^{c} \pm 0.453$ & $3.178 \pm$ & $30.83^{c} \pm 0.241$ & $3.612 \pm$ & $28.65^{c} \pm 0.024$ & $3.520 \pm$ & $25.62^{c} \pm 0.465$ & $4.56 \pm$ \\
\hline 3.0 & $82.00^{\mathrm{d}} \pm 1.525$ & 0.035 & $53.88^{d} \pm 0.303$ & 0.003 & $50.45^{d} \pm 0.575$ & 0.011 & $43.49^{d} \pm 0.457$ & 0.013 & $32.51^{\mathrm{d}} \pm 0.519$ & 0.039 \\
\hline 4.0 & $86.67 \mathrm{e} \pm 01.587$ & & $62.27 \mathrm{e} \pm 0.378$ & & $57.88 \pm \pm 0.455$ & & $57.24 \mathrm{e} \pm 0.498$ & & $47.39 \mathrm{e} \pm 0.498$ & \\
\hline 5.0 & $89.26^{\mathrm{f}} \pm 0.156$ & & $64.27^{\mathrm{f}} \pm 0.567$ & & $59.06^{\mathrm{f}} \pm 0.432$ & & $57.77 \mathrm{e} \pm 0.212$ & & $52.31^{\mathrm{f}} \pm 0.412$ & \\
\hline
\end{tabular}

Table 7: The percent inhibition of a-glucosidase by methanol, ethanol, ethyl acetate and pet ether extracts of S. persica leaves at varying concentrations.

\begin{tabular}{|c|c|c|c|c|c|c|c|c|c|c|}
\hline \multirow{2}{*}{$\begin{array}{l}\text { Conc. } \\
(\mathrm{mg} / \mathrm{ml})\end{array}$} & \multicolumn{2}{|c|}{ Acarbose } & \multicolumn{2}{|c|}{ Methanol } & \multicolumn{2}{|c|}{ Ethanol } & \multicolumn{2}{|c|}{ Ethyl acetaate } & \multicolumn{2}{|c|}{ Pet ether } \\
\hline & \%inhibition & $\mathrm{IC}_{50}$ & \%inhibition & $\mathrm{IC}_{50}$ & \%inhibition & $\mathrm{IC}_{50}$ & \%inhibition & $\mathrm{IC}_{50}$ & \%inhibition & $\mathrm{IC}_{50}$ \\
\hline 0.5 & $50.61^{a} \pm 0.429$ & & $13.87^{a} \pm 0.543$ & & $10.84^{a} \pm 0.441$ & & $9.09^{a} \pm 0.084$ & & $7.51^{a} \pm 0.199$ & \\
\hline 1.0 & $56.86^{b} \pm 0.494$ & & $24.71^{b} \pm 0.611$ & & $21.55^{\mathrm{b}} \pm 1.08$ & & $20.78^{\mathrm{b}} \pm 0.444$ & & $17.81^{\mathrm{b}} \pm 0.091$ & \\
\hline 2.0 & $70.23 c \pm 0.399$ & $0.059 \pm$ & $32.99 c \pm 0.410$ & $3.797 \pm$ & $29.65^{c} \pm 0.645$ & $3.941 \pm$ & $27.45^{c} \pm 0.506$ & $4.219 \pm$ & $24.43^{c} \pm 0.400$ & $5.125 \pm$ \\
\hline 3.0 & $82.00^{d} \pm 1.525$ & 0.035 & $43.83^{d} \pm 0.567$ & 0.027 & $36.05^{d} \pm 0.517$ & 0.011 & $32.21^{\mathrm{d}} \pm 0.177$ & 0.014 & $31.30^{d} \pm 0.546$ & 0.021 \\
\hline 4.0 & $86.67 \mathrm{e} \pm 01.587$ & & $56.19 e \pm 0.385$ & & $56.17 \mathrm{e} \pm 0.468$ & & $49.99 \mathrm{e} \pm 0.366$ & & $43.11^{\mathrm{e}} \pm 0.504$ & \\
\hline 5.0 & $89.26^{f} \pm 0.156$ & & $62.41^{\mathrm{f}} \pm 0.140$ & & $59.29^{f} \pm 0.413$ & & $52.19^{\mathfrak{f}} \pm 0.464$ & & $47.61^{\mathrm{f}} \pm 0.527$ & \\
\hline
\end{tabular}

Overall, the best activity was recorded in $C$. tagal leaves followed by leaves of B. cylindrica and S. persica. In C. tagal best a-amylase inhibition was recorded in methanol extract $(73.26 \%)$ followed by ethanol $(62.76 \%)$, ethyl acetate $(61.83 \%)$ and pet ether $(54.45 \%)$ at higher concentration (Table 2). Results of similar magnitude were recorded for a-glucosidase assay. These results indicate that methanol is the best solvent for the extraction of antidiabetic principle in this plant. There are no reports on in vitro antidiabetic activity in this plant however; in vivo antidiabetic activity has been recorded in the leaves of $C$. tagal [33]. This confirms antidiabetic potential in leaves of $C$. tagal. In $B$. cylindrica also the highest a-amylase inhibition was recorded in methanol extract than other solvent extracts. Similar results were recorded for aglucosidase assay. Like-wise lower a-amylase inhibition was recorded in methanol extract of S. persica than other solvents at higher concentrations. The result of the plant indicates slightly lower antidiabetic activity in the leaves of B. cylindrica and S. persica than C. tagal. Overall highest in vitro antidiabetic potential indicated in C. tagal followed by B. cylindrica and S. persica besides this methanol was found to be the best solvent for the extraction of antidiabetic principle. 
Antidiabetic potential of the plants is related to the presence of alkaloid, flavonoid, saponin, terpenoids classes of secondary metabolites [25-28], which all are seen in C. tagal, B. cylindrica and S. persica in this study. Therefore, the antidiabetic potential of the selected mangroves can be related to these phytochemicals. However the quantity and quality of these phytochemicals may be responsible for the antidiabetic potency of selected mangrove species.

This study proves that $C$. tagal exhibited maximum inhibitory activity in both the assays out of the mangrove species selected, thus establish a good relationship with the antidiabetic properties. This implicates the probability of containing some herbal bioactive compounds in plant which are inhibiting the activity of the enzyme, so in future; the identification of the bioactive constituents needs isolation, structural elucidation, and characterization.

\section{ACKNOWLEDGMENT}

The author expresses immense gratitude to University Grant Commission for providing financial support. We are also thankful to the Department of Life Sciences, University of Mumbai for instrumental help.

\section{REFERENCES}

1. Burke JP, Williams K, Narayan KV, Leibson C, Haffner SM, Stern MP. A population perspective on diabetes prevention: whom should we target for preventing weight gain? Diabetes care. 2003 Jul 1;26(7):1999-2004.

2. Parks M, Rosebraugh C. Weighing risks and benefits of liraglutide - the FDA's review of a new antidiabetic therapy. New England Journal of Medicine. 2010 Mar 4;362(9):774-7.

3. Kathiresan K, Bingham BL. Biology of mangroves and mangrove ecosystems. Advances in Marine Biology. 2001; 81-251.

4. Das SK, Patra JK, Thatoi H. Antioxidative response to abiotic and biotic stresses in mangrove plants: A review. International Review of Hydrobiology. 2016 Apr;101(1-2):319.

5. Revathi P, Thirumalaikolundusubramanian P, Prabhu N. Medicinal properties of mangrove plants-an overview. International Journal of Bioassays. 2013 Dec 1;2(12):1597-600.

6. Agshikar NV, Naik VR, Abraham GJ, Reddy CV, Naqvo SW, Mittal PK. Analgesic anti-inflammatory activity of Acanthus illicifolius Linn. Indian journal of experimental biology. 1979 Nov;17(11):1257-8.

7. Perry LM, Metzger J. Medicinal plants of East and Southeast Asia: attributed properties and uses. MIT press; 1980.

8. Santos AC, Santos GA, Obligacion MB. Philippine plants and their contained natural products: biological and pharmacological literature survey. National Research Council of the Philippines (NRCP), Bicutan, Taguig, Metro Manila. 1981.

9. Duke JA, Wain KK. Medicinal Plants of the World. 3 vol. Computer index with more than 85,000 entries. Plants genetics and germplasm Institute. Agriculture Research Service, Beltsville, Maryland. 1981.

10. Adhikari A, Ray M, Sur TK, Biswas S, Das AK. Comparative evaluation of antidiabetic activity of fresh juice and ethanolic extract of Sunderban mangrove Rhizophora mucronata Lam. leaves in animal model. International Journal of Basic and Clinical Pharmacology 2017; 6:2193-2198.

11. Islam MS, Rahman MF, Raju MA, Parvez M, Rakib HH, Shome B. A review on traditional ayurvedic medicinal plants used in the sundarban mangrove forest in Bangladesh. International Journal of Research in
Pharmacology and Pharmacotherapeutics. 2015;4(1), 37-44.

12. Mahmud I, Islam MK, Saha S, Barman AK, Rahman MM, Anisuzzman M, Rahmatullah M. Pharmacological and ethnomedicinal overview of Heritiera fomes: Future Prospects. International Scholarly Research Notices. 2014; 2014:1-12.

13. Lawag IL, Aguinaldo AM, Naheed S, Mosihuzzaman M. aGlucosidase inhibitory activity of selected Philippine plants. Journal of ethnopharmacology. 2012 Oct 31;144(1):217-9.

14. Haque M, Ahmed A, Nasrin S, Rahman MM, Raisuzzaman S. Revelation of mechanism of action of Rhizophora mucornata bark extracts for its antidiabetic activity by gut perfusion and six segment method in long evan rats. International Research Journal of Pharmacy. 2013; 4:1-4.

15. Srivastava SP, Mishra A, Lakshmi V, Tamrakar AK, Srivastava MN, Srivastava AK. Antidiabetic and antidyslipidemic activity of ethyl acetate fractions of Xylocarpus granatum and Xylocarpus molluccensis on high fructose high fat AND high sucrose high fat fed-low dosed streptozotocin treated diabetic rats. International Journal of Pharmacy and Pharmaceutical Sciences. 2015; 7(2), 537-543.

16. Patra JK, Das SK, Thatoi H. Phytochemical profiling and bioactivity of a mangrove plant, Sonneratia apetala, from Odisha Coast of India. Chinese journal of integrative medicine. 2015 Apr 1;21(4):274-85.

17. Morada NJ, Metillo EB, Uy MM, Oclarit JM. Anti- diabetic polysaccharide from mangrove plant, Sonneratia alba Sm. International Conference on Asia Agriculture and Animal. International Proceedings of Chemical, Biological and Environmental Engineering 2011 July; 13:197-200.

18. Nabeel MA, Kathiresan, K, Manivannan S. Antidiabetic activity of the mangrove species Ceriops decandra in alloxan induced diabetic rats. Journal of Diabetes. 2010;2(2), 97-103.

19. Ranjana, Jadhav BL, Dhavan PP, Patel P. In vitro antidiabetic activity and phytochemical analysis of Lumnitzera racemosa leaves. International Research Journal of Pharmacy 2019;10(4):220-227.

20. Gawali P, Jadhav BL. Antioxidant activity and phytochemical analysis of mangrove species Sonneratia alba and Bruguiera cylindrical. Asian Journal of Microbiology, Biotechnology and Environmental Sciences. 2011;13(2):257-261.

21. Jadhav BL, Quraishi FM, Pagare BG. "Evaluation of Antioxidant Properties and Phytochemical analysis in the stem and leaves of Ceriops tagal mangroves." Research journal of Biotechnology. 2013;8(9), 28-31.

22. Maurya BR. Studies on the bioactive components of alcoholic stem extract of Sonneratia apetala. Ph.D. Thesis (Life Sciences), Mumbai University, Mumbai; 2007.

23. Crozier A, Jaganath IB, Clifford MN. Dietary phenolics: Chemistry, bioavailability and effects on health. Natural Product Reports .2009;26(8):1001-1043.

24. Shyam T, Ganapaty S. Evaluation of antidiabetic activity of methanolic extracts from the aerial parts of Barleria montana in streptozotocin induced diabetic rats. Journal of Pharmacognosy and Phytochemistry 2013;2:187-92.

25. Wangensteen H, Dang HC, Uddin SJ, Alamgir M, Malterud KE. Antioxidant and antimicrobial effects of the mangrove tree Heritiera fomes. Natural Product Communications 2009 Mar; 4(3):371-376.

26. Li MY, Xiao Q, Pan JY, Wu J. Natural products from semimangrove flora: source, chemistry and bioactivities. Natural Product Reports 2009; 26:281-298.

27. Cheng F, Zhou Y, Wu J. Chemical constituents of fruit of Xylocarpus granatum. Journal of Chinese Medicinal Materials 2009; 32:1220-1223.

28. Nebula M, Harisankar HS, Chandramohanakumar N. Metabolites and bioactivities of Rhizophoraceae mangroves. Natural Products and Bioprospecting 2013; 3:207-232.

29. Harborne JB. Phytochemical methods: a guide to modern techniques of plant analysis. 2nd Ed. London (GB): Chapman and Hall Ltd; 1973.

30. Adisakwattana S, Ruengsamran T, Kampa P, Sompong W. In vitro inhibitory effects of plant-based foods and their combinations on intestinal a-glucosidase and pancreatic a- 
Ranjana et al. / Phytochemical Composition, in vitro Studies on a-Amylase and a-Glucosidase Inhibitory

amylase. BMC Complementary and Alternative Medicine 2012; 12(1):110.

31. Krishnaveni S, Balasubramanian T, Sadasivam S. Sugar distribution in sweet stalk sorghum. Food Chemistry 1984; 15(3):229-232.

32. Quraishi F, Studies on the Antioxidant properties and phytochemical analysis of selected mangrove species, Ph.D. Thesis, University Of Mumbai, 2017.
33. Tiwari P, Tamrakar AK, Ahmad R, Srivastava MN, Kumar R, Lakshmi V, Srivastava AK. Antihyperglycaemic activity of Ceriops tagal in normoglycaemic and streptozotocin-induced diabetic rats. Medicinal Chemistry Research. 2008 Jun 1;17(27):74-84.

HOW TO CITE THIS ARTICLE: Ranjana, Jadhav BL. Phytochemical Composition, in vitro Studies on a-Amylase and a-Glucosidase Inhibitory Activity of Selected Mangrove Plants. Int. J. Pharm. Sci. Drug Res. 2019; 11(5): 181186. DOI: 10.25004/IJPSDR.2019.110505 